\title{
The Influence of Discontinuities on Rock Mass Quality and Overall Stability of Andesite Rock Slope in West Java
}

Rudarsko-geološko-naftni zbornik

(The Mining-Geology-Petroleum Engineering Bulletin) UDC: $551.2 ; 551.3$

DOI: 10.17794/rgn.2020.3.7

Professional paper

\author{
Alvian Rizky Yanuardian', Koko Hermawan' ${ }^{1}$, Antonina Pri Martireni' ${ }^{1}$, Adrin Tohari ${ }^{1}$ \\ ${ }^{1}$ Research Center for Geotechnology, Indonesian Institute of Sciences, Bandung, Indonesia
}

\begin{abstract}
Open-pit mining constitutes a necessary activity for the extraction of rocks and minerals from the Earth. However, openpit mining activities often result in rock slope stability issues related to the discontinuities of rock masses. Thus, an appropriate cut-slope design in open-pit mining requires good knowledge of the effects of discontinuity on rock mass strength and quality. This study aims to analyze the effect of discontinuity type on rock quality and slope stability. Discontinuity data was collected from the columnar jointed-andesite rock slope in West Java. The analysis showed that the examined andesite slope has a good rock mass quality and very favorable slope stability. However, wedge-type slope failure may occur, which is substantially affected by columnar joints present in the rock mass. Moreover, the analysis indicated that the integral discontinuities present in the andesite outcrops significantly affect the mean values of the discontinuity length, discontinuity spacing, and rock strength. However, the integral discontinuities have little effect on the slope mass rating (SMR). Thus, detailed studies on the contribution of integral discontinuities to the rock mass rating and SMR of different rock types are recommended.
\end{abstract}

Keyword:

andesite rock; columnar joint; integral discontinuity; rock mass rating (RMR); slope mass rating (SMR)

\section{Introduction}

Open-pit mining is a necessary activity for the extraction of rocks and minerals from the Earth. This mining method may require excessive steepening of a rock slope, and consequently, cause a rock slope failure (Singh et al., 2013). Among other factors, the stability of rock slopes is strongly affected by the presence of rock mass discontinuities, because the discontinuities control not only the overall structure of the rock mass but also its mechanical properties, and consequently, the slope hydrogeology (Tating et al., 2015). Therefore, discontinuities impact the open mining design (Bye \& Bell, 2001).

The formation of rock discontinuities is generally associated with tectonic processes (Stead \& Wolter, 2015), magmatic activity (Hatzor et al., 2015), sedimentation (Tang et al., 2017), and weathering processes (Hencher \& Knipe, 2007). One discontinuity characteristic that is caused by magmatic activity is the development of fractures throughout the body of igneous rocks, which results in the formation of a polygon-shaped colonnade, the so-called columnar jointing (Goehring et al., 2006). Previously, researchers have focused on the analysis of the effect of the columnar joints on rock

Corresponding author: Alvian Rizky Yanuardian

alvian.ry@gmail.com slope stability. Majeed and Bakar (2015) used the kinematic approach to analyze the joint orientation data, and thereby, identify the failure mode of three rock slope faces. Based on the study of the orientation of joints in six lava domes, Smith (2018) found that the orientation of radial cooling joints is highly susceptible to toppling. Other studies showed how weathering processes affect the properties of mechanical discontinuities (Arikan \& Aydin, 2012; Tating et al., 2015). These studies showed that the spacing of discontinuities decreases with an increase in the weathering grades.

In contrast, Ehlen (2002) studied the effects of the weathering process on the discontinuity properties of weathered granitic rocks and found no clear relation between the spacing and length of the discontinuities and weathering grades. A study on the effect of weathering on the properties of sandstone discontinuities (Tating et al., 2018) showed that the iron-oxide precipitation in the discontinuities reduces the susceptibility of sandstones to weathering and increases their shear strength. Although many previous studies have shown how the properties of main discontinuities contribute to rock mass quality, none of them have attempted to evaluate the contribution of other types of discontinuities, such as integral discontinuities, to rock mass quality and slope stability. According to Tating et al. (2015), integral discontinuities can be formed from mechanical discontinuities by cementation or mineralization. 


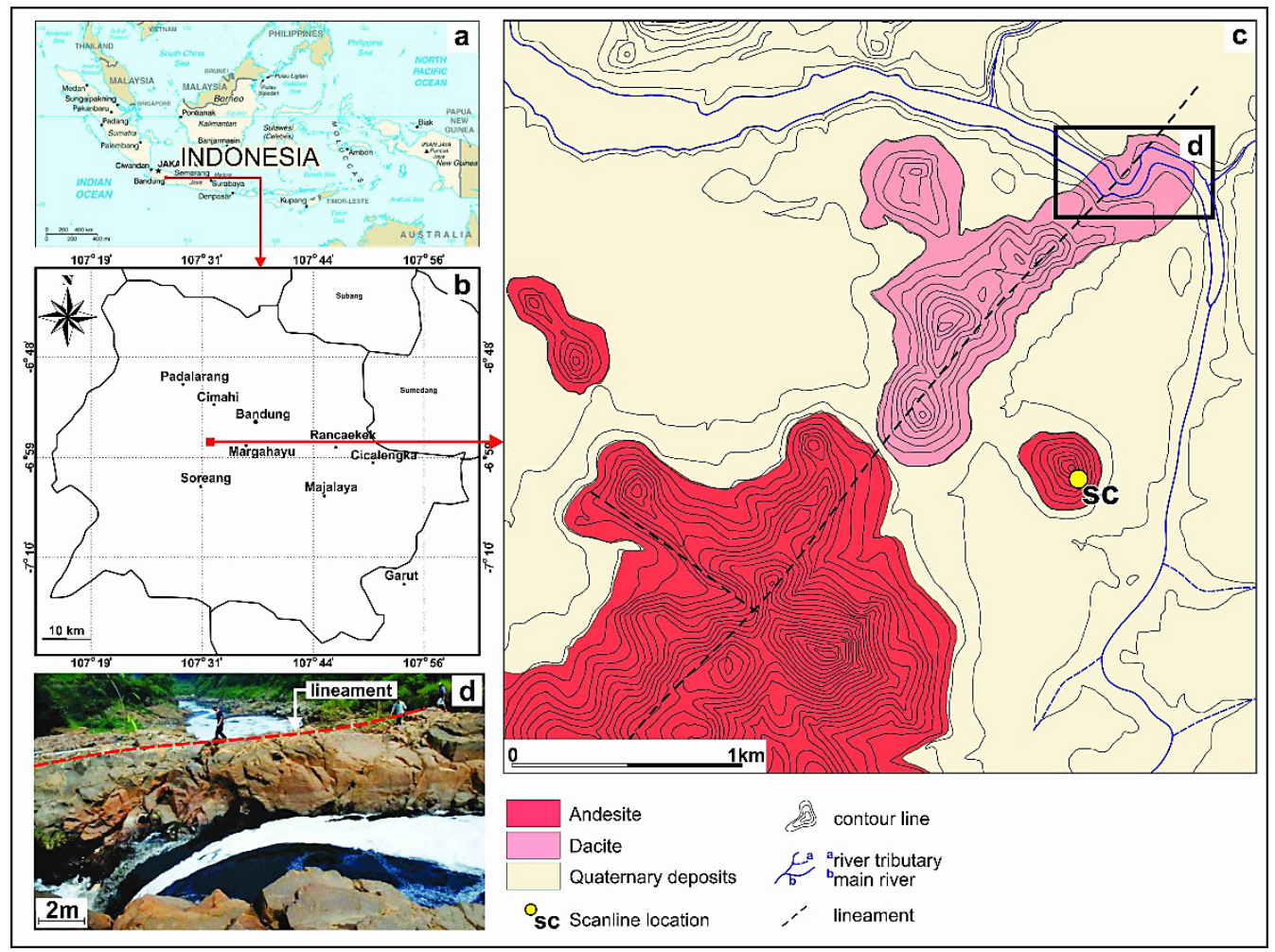

Figure 1: Geological map of the study area (modified from Silitonga, 1973).

The picture shows the lineament crossing the river (courtesy of www.bandungsiana.com).

This paper presents the results of mapping of the discontinuity characteristics in the andesite outcrop, which can be used to evaluate the contribution of various discontinuities on rock mass quality and slope stability. The discontinuity dataset was collected from an andesite outcrop in the Lagadar mining area located in West Java, Indonesia (see Figure 1).

\section{Methods}

This study is primarily based on field observations and measurements of discontinuities. The rock mass quality was assessed using rock mass rating (RMR), according to Bieniaswki (1989), and the rock slope stability was calculated using the modified Slope Mass Rating (SMR) proposed by Anbalagan et al. (1992) and Zheng et al. (2016).

\subsection{Study area}

Lagadar is a site of abandoned andesite mine pits in West Java, Indonesia, which is located about $16 \mathrm{~km}$ southwest of Bandung City. The outcrop of andesite is of Miocene age and is surrounded by Quaternary deposits (Silitonga, 1973), as shown in Figure 1. The lineament of the contour line of the hills and river bend in the northeast part of the study area can be interpreted as a fault, which runs in a northeast-southwest direction. The andesite and dacite outcrops are probably associated with this fault.
The outcrop has a high density of discontinuities that are associated with the cooling of igneous rocks. The discontinuities belong mainly to columnar sets that are characterized by variable azimuth and dip angle. The azimuth and dip angle of the discontinuity affect the type of rock slope instability (Hoek \& Bray, 1989; Mandalawi et al., 2016; Park et al., 2016; Wyllie \& Mah, 2014; Ye et al., 2012).

The height of the studied slope is up to $25 \mathrm{~m}$. The slope face has a southeast azimuth and the dip angle is $75^{\circ}$. On the other side, the height of the columnar joints is up to $18 \mathrm{~m}$. The columnar joint outcrop is divided into two engineering geological units. The upper unit is characterized by a higher density of discontinuities and higher degree of weathering, compared to the lower unit (see Figure 2).

\subsection{Rock Mass Rating (RMR) and Slope Mass Rating (SMR)}

Discontinuity data was recorded using a scanline in unit 1 (lower engineering geological unit) of the andesite outcrop. This unit was characterized by mappable discontinuities, which were free from the blasting effect. The scanline measurement was carried out only at the lower part of the slope due to limited access to the upper part. The discontinuity data was used to identify rock mass quality, according to Bieniawski (1989). The Schmidt hardness rebound numbers $\left(H_{r}\right)$ that were recorded using tests on 45 points (30 points on columnar 


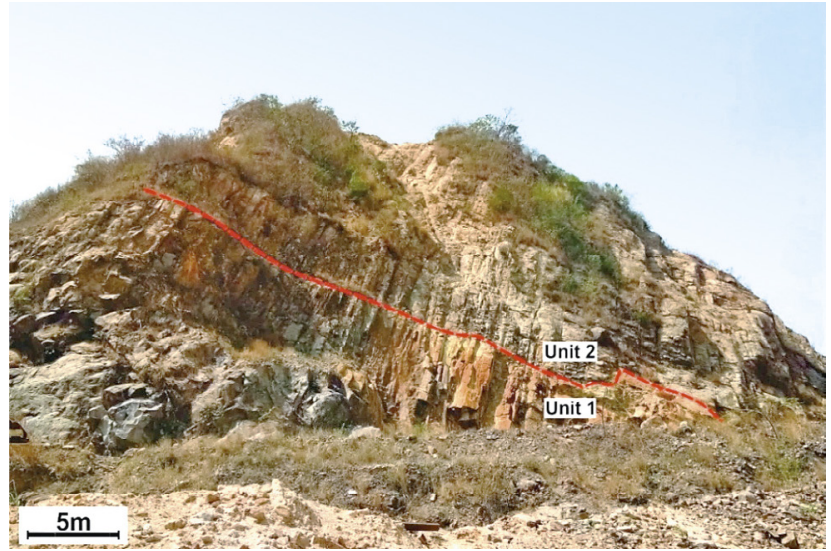

Figure 2: Outcrop of andesite in the study area.

Unit 1 is the lower engineering geological unit and unit 2 is the upper engineering geological unit. The red line represents the boundary between the two units. joints without integral discontinuities and 15 points near integral discontinuities) (see Figure 3) were converted into unconfined compressive strength (UCS) values. Several researchers, such as Armaghani et al. (2016), Gupta (2009), Aydin and Basu (2005), and Dinçer et al. (2004), developed a formula to convert $H_{r}$ values into UCS values for igneous rocks. The formula of Dincer et al. (2004) was considered appropriate for the current study, since it was developed based on tests conducted on a similar rock type (Equation 1). $H_{r}$ values were statistically analyzed to obtain the average values using the Statistical Package for Social Science (SPSS) software. Meanwhile, rock quality designation (RQD) was calculated using Equation 2, according to Priest and Hudson (1976). The observation and assessment criteria of the weathering grade followed the guideline of BS 5930:1981(1981).

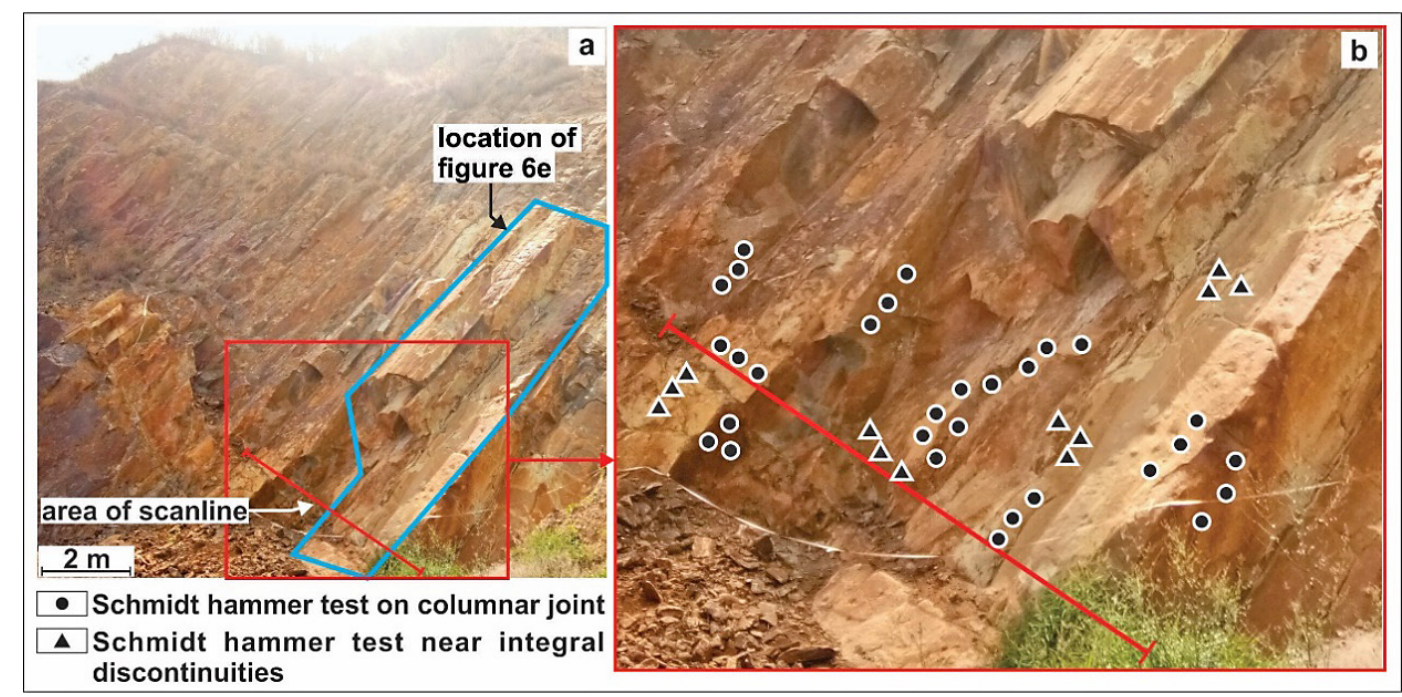

Figure 3: (a) Location of scanline and (b) Schmidt hammer test of columnar joint and integral discontinuities

Table 1: SMR used in this study [modified from Romana (1985) by Anbalagan et al. (1992) with proposed determination method for F1 and $F_{3}$ by Zheng et al. (2016)].

\begin{tabular}{|c|c|c|c|c|c|c|c|c|}
\hline \multirow[t]{2}{*}{ Factor } & \multicolumn{2}{|c|}{ Continuous Function } & \multirow{2}{*}{$\begin{array}{l}\text { Type of } \\
\text { Failure }\end{array}$} & \multirow{2}{*}{$\begin{array}{c}\text { Very } \\
\text { favorable }\end{array}$} & \multirow{2}{*}{ Favorable } & \multirow{2}{*}{ Normal } & \multirow{2}{*}{ Unfavorable } & \multirow{2}{*}{$\begin{array}{c}\text { Very } \\
\text { unfavorable }\end{array}$} \\
\hline & $\left|\alpha_{d}-\alpha_{s}\right| \leq 180^{\circ}$ & $\left|\alpha_{d}-\alpha_{s}\right|>180^{\circ}$ & & & & & & \\
\hline \multirow[t]{3}{*}{$\mathrm{F}_{1}$} & $\gamma_{P}=\left|\alpha_{d}-\alpha_{s}\right|$ & $360^{\circ}-\left|\alpha_{d}-\alpha_{s}\right|$ & \multirow{3}{*}{$\begin{array}{c}P / \\
W / \\
T\end{array}$} & $>30^{\circ}$ & $30-20^{\circ}$ & $20-10^{\circ}$ & $10-5^{\circ}$ & $<5^{\circ}$ \\
\hline & $\gamma_{W}=\left|\alpha_{\mathrm{i} \mid}-\alpha_{\mathrm{s}}\right|$ & $360^{\circ}-\left|\alpha_{i 1}-\alpha_{s}\right|$ & & 0.15 & 0.40 & 0.70 & 0.85 & 1.0 \\
\hline & $\gamma_{T}=180^{\circ}-\left|\alpha_{\mathrm{d}}-\alpha_{\mathrm{s}}\right|$ & $\left|\alpha_{d}-\alpha_{s}\right|-180^{\circ}$ & & & & & & \\
\hline \multirow[t]{3}{*}{$\mathrm{F}_{2}$} & \multicolumn{2}{|l|}{$\eta_{P / T}=\beta_{\mathrm{j}}$} & & $<20^{\circ}$ & $20-30^{\circ}$ & $30-35^{\circ}$ & $35-45^{\circ}$ & $>45^{\circ}$ \\
\hline & \multirow{2}{*}{\multicolumn{2}{|c|}{$\eta_{W}=\beta_{\mathrm{il}}$}} & $P / W$ & 0.15 & 0.40 & 0.70 & 0.85 & 1.0 \\
\hline & & & $T$ & 1.0 & 1.0 & 1.0 & 1.0 & 1.0 \\
\hline \multirow[t]{4}{*}{$F_{3}$} & \multicolumn{2}{|l|}{$\zeta_{P}=\beta_{\mathrm{d}}-\beta_{\mathrm{sa}}$} & $P / W$ & $>10^{\circ}$ & $10-0^{\circ}$ & $0^{\circ}$ & $0-\left(-10^{\circ}\right)$ & $<\left(-10^{\circ}\right)$ \\
\hline & \multicolumn{2}{|l|}{$\zeta_{W}=\beta_{\mathrm{il}}-\beta_{\mathrm{sa}}$} & $T$ & $<110^{\circ}$ & $110-120^{\circ}$ & $>120^{\circ}$ & - & - \\
\hline & \multicolumn{2}{|l|}{$\zeta_{T}=\beta_{\mathrm{d}}+\beta_{\mathrm{sa}}$} & & 0 & -6 & -25 & -50 & -60 \\
\hline & \multicolumn{2}{|c|}{$\beta_{\mathrm{sa}}=\alpha \tan \left(\tan \beta_{\mathrm{s}} \cos \gamma_{\mathrm{P} / \mathrm{WT}}\right)$} & & & & & & \\
\hline
\end{tabular}

$P$ is the planar failure; $T$ is the toppling failure; $W$ is the wedge failure; $\alpha_{d}$ is the azimuth of discontinuity; $\alpha_{s}$ is the azimuth of the slope face; $\alpha_{i l}$ is the azimuth of the intersection line; $\beta_{d}$ is the dip angle of the discontinuity; $\beta_{s}$ is the dip angle of the slope; $\beta_{s a}$ is the apparent dip angle of the slope in the direction of the azimuth of the discontinuity; $\beta_{i l}$ is the dip angle of the intersection line; $\gamma$ is the value of $F_{1} ; \eta$ is the value of $\boldsymbol{F}_{2} ;$ and $\zeta$ is the value of $\boldsymbol{F}_{3}$ 


$$
\begin{gathered}
U C S=2.75 H_{r}-36.83 \\
R Q D=100 e^{-0.1 \lambda} \times(0.1 \lambda+1)
\end{gathered}
$$

Table 2: Scoring of the adjustment factor according to the excavation methods $\left(\boldsymbol{F}_{\mathbf{4}}\right)$

\begin{tabular}{|l|c|c|c|}
\hline Type & Score & Type & Score \\
\hline Presplitting & +10 & Blasting or mechanical & 0 \\
\hline $\begin{array}{l}\text { Smooth } \\
\text { blasting }\end{array}$ & +8 & Natural slope & +15 \\
\hline
\end{tabular}

where $H_{r}$ indicates the Schmidt hardness rebound numbers and $\lambda$ is the mean number of discontinuities per meter.

The azimuths and dip angles of discontinuities and slopes are used for the kinematic analysis using stereographic projection, following Goodman (1989). According to Azzam et al. (2018), the friction angle of slightly weathered andesite in West Java is around $35^{\circ}$. Thus, the current study considered $35^{\circ}$ as the friction angle to be used for kinematic analysis. The results of rock mass quality analysis and the kinematics analysis were

Table 3: Stability classes

\begin{tabular}{|l|c|c|c|c|c|}
\hline Classes & V & IV & III & II & I \\
\hline SMR & $0-20$ & $21-40$ & $41-60$ & $61-80$ & $81-100$ \\
\hline Description & Very bad & Bad & Normal & Good & Very good \\
\hline Stability & Completely unstable & Unstable & Partially unstable & Stable & Completely stable \\
\hline
\end{tabular}

Table 4: Statistic values of discontinuity properties

\begin{tabular}{|l|c|c|c|c|c|}
\hline & $\begin{array}{c}\text { Number } \\
\text { of data }\end{array}$ & $\begin{array}{c}\text { Minimum } \\
\text { value }\end{array}$ & $\begin{array}{c}\text { Maximum } \\
\text { value }\end{array}$ & $\begin{array}{c}\text { Mean } \\
\text { value }\end{array}$ & $\begin{array}{c}\text { Standard } \\
\text { deviation }\end{array}$ \\
\hline$H_{r}$ & 45 & 11 & 46 & 28.18 & 8.27 \\
\hline Spacing of discontinuities (cm) & 14 & 4 & 41 & 18.00 & 11.62 \\
\hline Length of discontinuities (m) & 16 & 0.08 & 17 & 2.8 & 4.42 \\
\hline Aperture (mm) & 15 & 0.05 & 2.2 & 0.65 & 0.64 \\
\hline
\end{tabular}
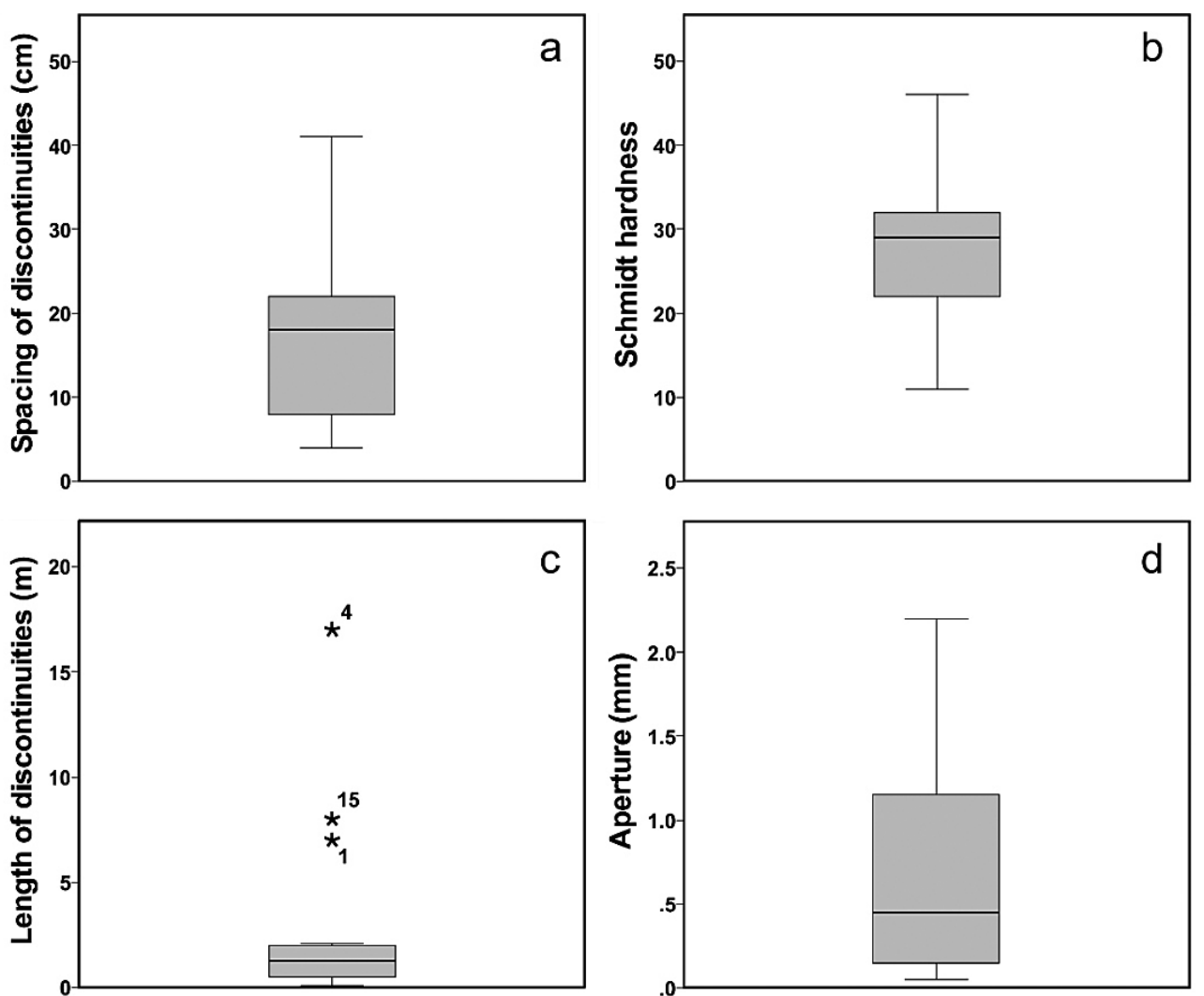

Figure 4: Boxplot of (a) spacing of discontinuities, (b) Schmidt hardness,

(c) length of discontinuities (the stars with numbers 1, 4, and 15 indicate the extreme data of columnar joint lengths), and (d) aperture of the discontinuities 


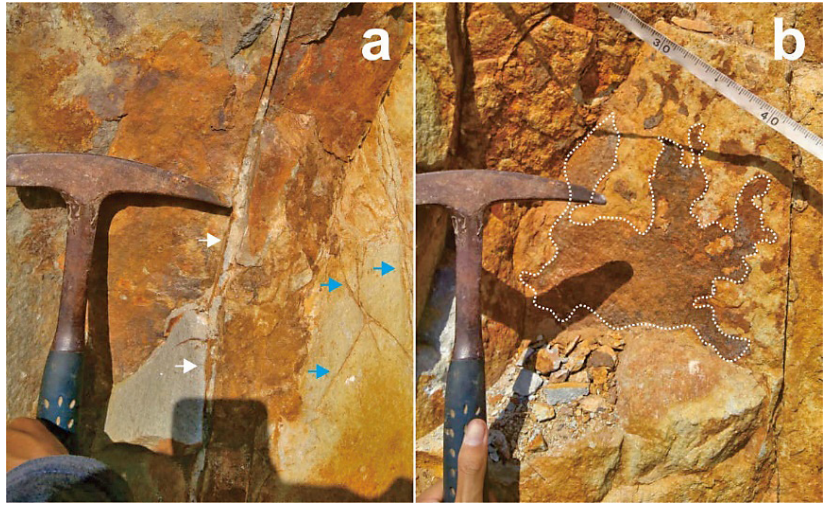

Figure 5: (a) Columnar joint (white arrows) and integral discontinuities (blue arrows) filled with iron oxide, and (b) the appearance of iron oxide (length of hammer $\approx 30 \mathrm{~cm}$ )
Table 5: Rock mass quality of the study area

\begin{tabular}{|c|c|c|}
\hline Parameters & Value/condition & Score \\
\hline Intact rock strength (MPa) & 40.4 & 4 \\
\hline RQD & 88 & 17 \\
\hline Spacing of discontinuities (cm) & 18 & 8 \\
\hline Length of discontinuities (m) & 2.8 & 4 \\
\hline Aperture (mm) & 0.84 & 4 \\
\hline Roughness & slightly rough & 3 \\
\hline Infilling material & hard, iron oxide & 4 \\
\hline Weathering grade & $\begin{array}{c}\text { slightly } \\
\text { weathered }\end{array}$ & 5 \\
\hline Groundwater & dry & 15 \\
\hline Total score & & 64 \\
\hline Classification & & Good \\
\hline
\end{tabular}
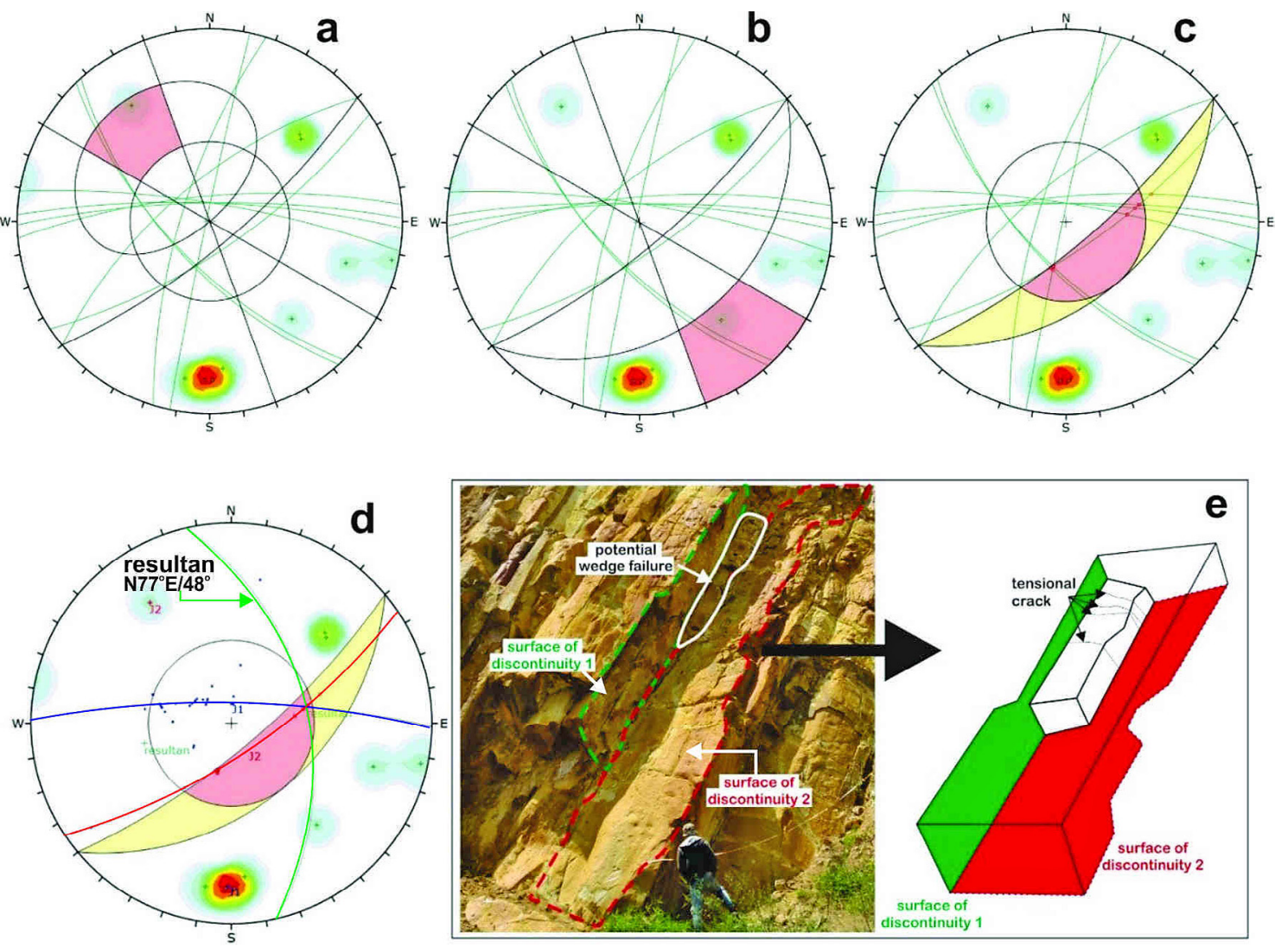

Figure 6: Kinematic analysis of (a) planar failure, (b) toppling, (c) wedge failure,

(d) azimuth/dip angle of wedge failure, (e) 3D model of wedge failure in the field (height of person $\approx 1.60 \mathrm{~m}$ ).

Note: friction angle is determined from Azzam et al. (2018).

All kinematic data were plotted on lower hemisphere in Dips (2019).

used as a basis for the slope stability analysis, using the slope mass rating (SMR) method proposed by Romana (1985), which was modified by Anbalagan et al. (1992). The values for F1 and F3 were determined using the corrected methods proposed by Zheng et al. (2016), as shown in Table 1 . The values for F4 were obtained by referring to Table 2. According to SMR, slope stability is divided into five classes, completely stable (SMR 10081 ), stable (80-61), partially stable (60-41), unstable
(40-21), and completely unstable (20-0), as shown in Table 3.

\section{Results}

The characteristics of the discontinuities in the study area, obtained from 16 samples on both columnar and integral discontinuities, are presented in Table 4. The mean of $H_{r}$ obtained from 45 test locations is 28.18 (see 
Table 6: Slope stability calculation based on $S M R$

\begin{tabular}{|c|c|c|}
\hline Factors & Continuous Function & Score \\
\hline \multirow[t]{3}{*}{$\mathbf{F}_{1}$} & $\gamma_{\mathrm{W}}=\left|\alpha_{\mathrm{i} 1}-\alpha_{\mathrm{s}}\right|$ & $>30^{\circ}$ \\
\hline & $\gamma_{\mathrm{W}}=\left|77^{\circ}-140^{\circ}\right|$ & 0.15 \\
\hline & $=63^{\circ}$ & Very favorable \\
\hline \multirow[t]{3}{*}{$\mathbf{F}_{2}$} & $\mathrm{~B}_{\mathrm{W}}=\beta_{\mathrm{il}}$ & $>45^{\circ}$ \\
\hline & $\mathrm{B}_{\mathrm{W}}=48^{\circ}$ & 1.0 \\
\hline & & Very unfavorable \\
\hline \multirow[t]{4}{*}{$\mathbf{F}_{3}$} & $\zeta_{\mathrm{w}}=\beta_{\mathrm{il}}-\beta_{\mathrm{sa}}$ & $>10^{\circ}$ \\
\hline & $\begin{aligned} \zeta_{\mathrm{W}}= & 48^{\circ}-(\alpha \tan \times \\
& \left.\left(\tan \beta_{\mathrm{s}} \times \cos \gamma_{\mathrm{P} / \mathrm{W} / \mathrm{T}}\right)\right)\end{aligned}$ & 0 \\
\hline & $\begin{aligned} \zeta_{\mathrm{W}}= & 48^{\circ}-\left(140^{\circ} \times \tan \right. \\
& \left.\left(\tan 75^{\circ} \times \cos 63^{\circ}\right)\right)\end{aligned}$ & Very favorable \\
\hline & $\zeta_{\mathrm{W}}=43,9^{\circ}$ & \\
\hline $\mathbf{F}_{4}$ & Blasting or mechanical & 0 \\
\hline \multicolumn{2}{|c|}{ Total score $=\mathrm{RMR}+\left(\mathrm{F}_{1} \times \mathrm{F}_{2} \times \mathrm{F}_{3}\right)+\mathrm{F}_{4}$} & 64 \\
\hline \multicolumn{2}{|c|}{ Description } & Good \\
\hline \multicolumn{2}{|c|}{ Stability } & Stable \\
\hline
\end{tabular}

Table 4 and Figure 4). The discontinuities have a maximum and minimum spacing of 41 and $4 \mathrm{~cm}$, respectively, and their mean value is $18 \mathrm{~cm}$. The longest measured persistence is $1700 \mathrm{~cm}$, which is part of the columnar joints being the primary discontinuities. On the other hand, the shortest discontinuities are $8 \mathrm{~cm}$, which is a part of the integral discontinuities. However, the aperture values of integral discontinuities and columnar joints range between 0.05 and $2.2 \mathrm{~mm}$, with a mean value of approximately $0.65 \mathrm{~mm}$. The normal separation discontinuity data, except for the length of the discontinuities, are shown in Figure 4. The extreme data of columnar joint lengths are indicated by stars with numbers 1, 4, and 15 in Figure 4c.

Both discontinuities are slightly weathered and almost completely filled with iron oxide (see Figure 5), which is probably a consequence of chemical weathering. The weathering occurs not only in the discontinuities but also on the rock surface. Based on the RMR classification, the rock mass is of good quality (see Table 5). The mean of the intact rock strength based on the conversion of $H_{r}$ to UCS value is $40.4 \mathrm{MPa}$. Moreover, the RQD for $3.6 \mathrm{~m}$ of the scanline is $88 \%$. According to the scanline data, the discontinuity surfaces are slightly rough. The examination of the outcrop did not reveal any visible sign of groundwater presence.

The characteristics of the azimuth and dip angle of the integral discontinuities and columnar joints are different. However, the azimuth and dip angle of the integral discontinuities were not measurable because the integral discontinuity planes are not distinct. Thus, only 10 columnar joint data points were used for the kinematic analysis, to identify the type of rock failure in the study. The result of the analysis indicates that the rock failure types comprise planar-type failure $(10 \%)$, toppling $(10 \%)$, and wedge-type failure $(20 \%)$. The results of the kinematic analysis are in good agreement with the field condition. Observations and measurements in the field showed a wedge-type failure controlled by a columnar joint. In general, the azimuth and dip angle of the discontinuities that cause wedge failure are $\mathrm{N} 146^{\circ} \mathrm{E} / 72^{\circ}$ and $\mathrm{N} 1^{\circ} \mathrm{E} / 78^{\circ}$, respectively, and the orientation of the wedge failure is $\mathrm{N}^{\circ} 7^{\circ} \mathrm{E} / 48^{\circ}$ (see Figure 6).

Based on the rock mass quality values and adjustment factors of the discontinuities, the cut-slope in the study area showed a good stability with an SMR score of 64 (see Table 6). This result implies that the orientations of the discontinuities have no impact on the current stability of the studied slope. Nevertheless, slope maintenance is occasionally required to prevent any block failure during the mining activities.

\section{Discussion}

According to Saliba and Jagla (2003), there are two types of discontinuities in a columnar joint structure, i.e., the border of colonnades and striae. However, the columnar joints of the andesite outcrop in the studied slope are characterized only by a preserved border of colonnades, without any trace of striae. The absence of striae in the columnar joints suggests that striae were not well-developed, due to the rapid cooling of magma. Hence, the rock mass quality of andesite outcrops is strongly controlled by the colonnades, and no discontinuities have developed due to the weathering process.

The analysis of rock mass quality generally only considers the characteristics of the main discontinuities of colonnades; thus, it is considered that the genesis of the columnar joint controls the rock mass quality. On the other hand, the study area reveals the development of integral discontinuities due to iron oxide precipitation in the rock masses. As shown in Table 7, the spacing of integral discontinuities is also much shorter than that of columnar joints. Weathering processes result in an increased development of integral discontinuities on the rock mass. Instead, the formation of columnar joints stops as the cooling process of magma comes to an end. Previous studies have shown that the weathering process of rock slopes has significant control on the decrease in discontinuity spacing when the weathering degree increases (Arikan \& Aydin, 2012; Tating et al., 2015). However, Ehlen (2002) found no clear relation between the spacing and length of discontinuities and weathering grades in weathered granitic rocks.

Contrary to discontinuity spacing, the length and aperture of integral discontinuities contribute to a higher rating than that of the columnar joints. The length of integral discontinuities, measured in andesite rocks, is overall shorter than that of columnar joints. The length of integral discontinuity is controlled by the degree of weathering of the rock mass. In the current state, the weathering of the andesite rock mass produces only short discontinuities. Thus, the length of the integral discontinuities remains a factor which significantly contrib- 
Table 7: Comparison of $H_{r}$, the spacing of discontinuities, length of discontinuities and rating of RMR (Bieniawski, 1989) between integral discontinuities and columnar joints

\begin{tabular}{|c|c|c|c|}
\hline Parameter & $\begin{array}{c}\text { Integral } \\
\text { discontinuities }\end{array}$ & Columnar joints & $\begin{array}{l}\text { Difference } \\
\text { in rating }\end{array}$ \\
\hline$H_{r} /$ UCS (MPa) & $23.5(27.8)$ & $29.9(45.4)$ & \multirow{2}{*}{ 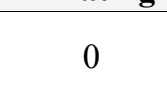 } \\
\hline Rating & 4 & 4 & \\
\hline Spacing of discontinuities (cm) & 18.6 & 91 & \multirow{2}{*}{-7} \\
\hline Rating & 8 & 15 & \\
\hline Length of discontinuities (cm) & 104.6 & 385.7 & \multirow{2}{*}{2} \\
\hline Rating & 4 & 2 & \\
\hline Aperture & 0.433 & 1.09 & \multirow[b]{2}{*}{3} \\
\hline Rating & 4 & 1 & \\
\hline Total & 20 & 22 & -2 \\
\hline
\end{tabular}

Table 8: Comparison of rock mass quality with and without integral discontinuities

\begin{tabular}{|c|c|c|c|}
\hline Parameters & $\begin{array}{c}\text { Score of } \\
\text { columnar joints }\end{array}$ & $\begin{array}{c}\text { Score of integral } \\
\text { discontinuities }\end{array}$ & $\begin{array}{c}\text { Overall score } \\
\text { of discontinuities }\end{array}$ \\
\hline Intact Rock Strength (MPa) & 4 & 4 & 4 \\
\hline RQD & 20 & 20 & 17 \\
\hline Spacing of discontinuities (cm) & 15 & 8 & 8 \\
\hline Length of discontinuities (cm) & 2 & 4 & 4 \\
\hline Aperture (mm) & 1 & 4 & 4 \\
\hline Roughness & 3 & 3 & 3 \\
\hline Infilling material & 4 & 4 & 4 \\
\hline Weathering grade & 5 & 5 & 5 \\
\hline Groundwater & 15 & 15 & 15 \\
\hline Total score & 69 & 67 & 64 \\
\hline Classification & Good & Good & Good \\
\hline
\end{tabular}

utes to the quality of the rock mass. Therefore, it is necessary to observe and measure the integral discontinuity, in order to have an accurate rock mass classification, which is required for the engineering design of rock slope stability.

Most of the integral discontinuities that are observed in the studied slope are infilled by iron oxide, which consequently closed the aperture of the discontinuities. Iron oxide is hard and less permeable, consequently preventing the water infiltration and increasing the rock mass rating (Tating et al., 2015). Thus, the presence of integral discontinuities in a rock mass can contribute to a decrease in rock mass rating, although that decrease is not very significant. Among the other parameters, the spacing of integral discontinuities plays an important role in reducing the rock mass quality of andesites in the study area. Thus, it is necessary to consider integral discontinuities when evaluating the quality of rock mass and the stability of rock slopes.

The integral discontinuities tend to have an undefined azimuth or dip angle. However, they have a significant impact on rock mass quality, which can be observed in the $H_{r}$ values obtained around integral discontinuities and columnar joints. The result shows that the mean of $H_{r}$ around the integral discontinuities is significantly smaller than the $H_{r}$ of the columnar joints (see Table 7). This is a result of the genesis of integral discontinuities which is associated with the weathering process by which weak minerals were formed in the discontinuity planes. Conversely, columnar joints are associated with magma cooling processes by which minerals similar to those in the rock masses were formed on the discontinuity planes. Thus, the hardness of columnar joints is higher than that of the integral discontinuity. The weathering process also causes the disintegration of minerals around integral discontinuities (Price et al., 2009; Hencher, 2013). Consequently, $H_{r}$ around the integral discontinuities affects the mean of intact rock strength and rock mass quality.

As shown in Table 8, the integral discontinuities appear to contribute to a decrease in the rock mass quality of the studied slope, because their development obviously increases the discontinuity spacing. Ehlen (2002) indicated that such a trace of integral discontinuity disappears as the weathering action progresses, resulting in a wider discontinuity spacing. In effect, the calculation of RMR will lead to an inaccurate rock mass classification, which can, in turn, affect the slope design. Tating et al. (2018) showed that the precipitation of iron minerals in discontinuities can increase the rock mass quality 
of sandstone outcrops because the iron mineral precipitation contributes to increasing the rock shear strength. Thus, further studies on the contribution of integral discontinuities in a weathered igneous rock to rock mass quality are strongly recommended.

\section{Conclusion}

An understanding of the complex geological condition is essential to solve a slope stability problem. The study carried out on the slope in the Lagadar mining area shows that rock slope stability is related to rock mass quality. The values of SMR and RMR are the same. Thus, all RMR parameters control the slope stability in the study area. Most of the parameters controlling the slope stability are characteristic of discontinuities, such as spacing, length, and aperture.

The characteristics of the columnar joint play a significant role in the type of rock failure, but those of integral discontinuities additionally affect the RMR and the value of slope stability. In the study area, the columnar joints show the widest spacing of discontinuities - consequently, the rock mass quality and SMR value increase. However, the spacing of integral discontinuity decreases the values of RMR and SMR. In addition, the $H_{r}$ around integral discontinuities decreases. Conversely, the length of the integral discontinuity increases the rock mass quality and value of slope stability. In contrast, the columnar joints show the opposite results.

Based on the present study, it is suggested that the integral discontinuities do not have a direct impact on failure type and the adjustment factor of discontinuities in SMR, because their orientation is not yet well-developed. Among the other parameters, only the spacing of integral discontinuities causes a decrease in rock mass quality. Thus, further studies are necessary to understand how the development of integral discontinuities may affect rock slope stability, and especially what impact the length and aperture have as they become longer and wider, respectively, during the process of weathering.

\section{Acknowledgment}

The publication of this research is supported by the funding scheme of the Deputy of Earth Sciences of the Indonesian Institute of Sciences (LIPI). The authors would like to acknowledge the Mining Engineering Program of Bandung Institute of Technology for permission to use Dips (2019). The authors would also like to express their gratitude to Mr. Aditya Sukur, formerly a student of Department of Geology of Jenderal Soedirman University in Purwokerto, Central Java, for his assistance in discontinuity mapping and sample collection.

\section{References}

Anbalagan, R., Sharma, S. and Raghuvanshi, T. K. (1992): Rock mass stability evaluation using modified SMR ap- proach. 6th National Symposium on Rock Mechanics. Proceedings, 1, 258-268.

Arikan, F. and Aydin, N. (2012): Influence of weathering on the engineering properties of dacites in Northeastern Turkey. ISRN Soil Science, 2012, 1-15. https://doi.org/ 10.5402/2012/218527.

Armaghani, D. J., Tonnizam, M. E., Momeni, E., Monjezi, M. and Sundaram, N. M. (2016): Prediction of the strength and elasticity modulus of granite through an expert artificial neural network. Arabian Journal of Geosciences, 9, 1, 1-16. https://doi.org/10.1007/s12517-015-2057-3.

Aydin, A. and Basu, A. (2005): The Schmidt hammer in rock material characterization. Engineering Geology, 81, 1, 1-14. https://doi.org/10.1016/j.enggeo.2005.06.006.

Azzam, M. A., Rinaldi, M., Wibowo, S., Zakaria, Z., Muslim, D. and Mulyo, A. (2018): Feasibility study of crushing plant location at Quarry Andesite, West Java, Indonesia, using rock mass classification and kinematic analysis. IOP Conference Series: Earth and Environmental Science, 145, 012056. https://doi.org/10.1088/1755-1315/145/1/012056.

Bieniawski, Z. T. (1989): Engineering rock mass classifications: a complete manual for engineers and geologists in mining, civil, and petroleum engineering. A Wiley-Interscience publication, Canada, $251 \mathrm{p}$.

Bye, A. R. and Bell, F. G. (2001): Stability assessment and slope design at Sandsloot open pit, South Africa. International Journal of Rock Mechanics and Mining Sciences, 38, 3, 449-466. https://doi.org/10.1016/S1365-1609(01) 00014-4.

Dinçer, I., Acar, A., Çobanoğlu, I. and Uras, Y. (2004): Correlation between Schmidt hardness, uniaxial compressive strength and Young's modulus for andesites, basalts and tuffs. Bulletin of Engineering Geology and the Environment, 63, 2, 141-148. https://doi.org/10.1007/s10064004-0230-0.

Dips (2019) Dips software. Plotting, analysis and presentation of structural data using spherical projection techniques. 7.0 edn. Rocscience, Toronto, Ontario, Canada.

Ehlen, J. (2002): Some effects of weathering on joints in granitic rocks. Catena, 49, 1-2, 91-109. doi:10.1016/s03418162(02)00019-x.

Goehring, L., Morris, S. W. and Lin, Z. (2006): Experimental investigation of the scaling of columnar joints. Physical Review E, 74, 3, 1-12. https:// doi:10.1103/physreve. 74.036115 .

Goodman, R. E. (1989): Introduction to rock mechanics. second edition. John Wiley and Sons, New York, 562p

Gupta, V. (2009): Non-destructive testing of some higher Himalayan Rocks in the Satluj Valley. Bulletin of Engineering Geology and the Environment, 68, 3, 409-416. https://doi.org/10.1007/s10064-009-0211-4.

Hatzor, Y. H., Feng, X.-T., Li, S., Yagoda-Biran, G., Jiang, Q. and $\mathrm{Hu}, \mathrm{L}$. (2015): Tunnel reinforcement in columnar jointed basalts: The role of rock mass anisotropy. Tunnelling and Underground Space Technology, 46, 1-11. https:// doi.org/10.1016/j.tust.2014.10.008.

Hencher, S. R. (2013): Characterizing discontinuities in naturally fractured outcrop analogues and rock core: the need 
to consider fracture development over geological time. Geological Society, London, Special Publications, 374, 1, 113-123. https://doi.org/10.1144/sp374.15.

Hencher, S. R. and Knipe, R. J. (2007): Development of rock joints with time and consequences for engineering. Proceedings of the 11th Congress of the International Society for Rock Mechanics, 1, 223-226.

Hoek, E. and Bray, J. (1989): Rock: Design, Excavation, Stabilization. In Technology (Issue September).

Majeed, Y. and Abu, B. M. (2015): Kinematic analysis of selected rock slopes along Choa Saidan Shah-Kallar Kahar Road Section. Journal of Faculty of Engineering \& Technology, 22, 2, 123-135.

Mandalawi, M. A., You, G., Dowling, K. and Dahlhaus, P. (2016): Kinematic assessment of slopes at Handlebar Hill Open Cut Mine, Mt. Isa, Queensland, Australia. International Journal of Geomate, 10, 1, 1575-1583. https://doi. org/10.21660/2016.19.09509.

Park, H. J., Lee, J. H., Kim, K. M. and Um, J. G. (2016): Assessment of rock slope stability using GIS-based probabilistic kinematic analysis. Engineering Geology, 203, 56-69. https://doi:10.1016/j.enggeo.2015.08.021.

Price, D. G., De Freitas, M. H., Hack, H. R. G. K., Higginbottom, I. E., Knill, J. L. and Maurenbrecher, M. (2009): Engineering geology: Principles and practice. Springer. Berlin, $468 \mathrm{p}$.

Priest, S. D. and Hudson, J. A. (1976): Discontinuity spacings in rock. International Journal of Rock Mechanics and Mining Sciences \& Geomechanics Abstracts, 13, 5, 135-148. https://doi:10.1016/0148-9062(76)90818-4.

Romana, M. (1985): New adjustment ratings for application of Bieniawski classification to slopes. Proceedings of the International Symposium on Role of Rock Mechanics, Zacatecas, Mexico, 49-53.

Saliba, R. and Jagla, E. A. (2003): Analysis of columnar joint patterns from three-dimensional stress modeling. Journal of Geophysical Research: Solid Earth, 108, B10. https:// doi.org/10.1029/2003jb002513.

Singh, T. N., Pradhan, S. P. and Vishal, V. (2013): Stability of slopes in a fire-prone mine in Jharia Coalfield, India. Arabian Journal of Geosciences, 6, 2, 419-427. https://doi. org/10.1007/s12517-011-0341-4.
Silitonga, P. H. (1973): Peta geologi lembar Bandung, Djawa: geologic map of the Bandung quadrangle, Java.

Smith, J. V. (2018): Susceptibility of lava domes to erosion and collapse by toppling on cooling joints. Journal of Volcanology and Geothermal Research, 349, 311-322. https:// doi.org/10.1016/j.jvolgeores.2017.11.015.

Standard, B. (1981): 5930, 1981. Code of Practice for Site Investigations. British Standards Institution, London, 147.

Stead, D. and Wolter, A. (2015): A critical review of rock slope failure mechanisms: The importance of structural geology. In Journal of Structural Geology, 74, 1-23. https://doi. org/10.1016/j.jsg.2015.02.002.

Tang, H., Yong, R. and Ez Eldin, M. A. M. (2017): Stability analysis of stratified rock slopes with spatially variable strength parameters: the case of Qianjiangping landslide. Bulletin of Engineering Geology and the Environment, 76, 3, 839-853. https://doi.org/10.1007/s10064-016-0876-4.

Tating, F., Hack, R. and Jetten, V. (2015): Weathering effects on discontinuity properties in sandstone in a tropical environment: case study at Kota Kinabalu, Sabah Malaysia. Bulletin of Engineering Geology and the Environment, 74, 2, 427-441. https://doi.org/10.1007/s10064-014-0625-5

Tating, F. F., Hack, H. R. G. K. and Jetten, V. G. (2018): Influence of weathering-induced iron precipitation on properties of sandstone in a tropical environment. Quarterly Journal of Engineering Geology and Hydrogeology, 52, 1, 46-60. https://doi.org/10.1144/qjegh2017-143

Wyllie, D. C. and Mah, C. (2014): Rock slope engineering : civil and mining $4^{\text {th }}$ edition "Based on Rock Slope Engineering (third edition, 1981) by Dr Evert Hoek and Dr John Bray. Spon Press, London.

Ye, H. W., Wu, K. and Wang, J. (2012): Stability analysis about slope of open pit mine based on fuzzy synthetic evaluation. Advanced Materials Research, 396-398, 2370-2374. https: //doi:10.4028/www.scientific.net/amr.396-398.2370

Zheng, J., Zhao, Y., Lü, Q., Deng, J., Pan, X. and Li, Y. (2016): A discussion on the adjustment parameters of the slope mass rating (SMR) system for rock slopes. Engineering Geology, 206, 42-49. https://doi.org/10.1016/j.enggeo. 2016.03.007

URL: http://www.bandungsiana.com/2016-11-29/untuk-atasibanjir-di-bandung-pupr-bangun-terowongan-air-di-curugjompong (accessed on 8th May 2020) 


\section{SAŽETAK}

\section{Utjecaj diskontinuiteta na kvalitetu stijenske mase i opću stabilnost andezitnih stijena na zapadnoj Javi}

Površinski kopovi nužni su u vađenju stijena i minerala iz zemlje. No površinski kopovi često uzrokuju probleme u stabilnosti stijenskih kosina koji su povezani s diskontinuitetom stijenske mase. Dakle, odgovarajući oblik reznih kosina u površinskim kopovima zahtijeva dobro poznavanje učinaka diskontinuiteta na snagu i kvalitetu stijenske mase. Svrha je ovoga rada razjasniti utjecaj tipa diskontinuiteta na kvalitetu stijene i stabilnost stijenske kosine. Podatci o diskontinuitetu prikupljani su u stijeni stupastih andezita u Zapadnoj Javi. Analiza je pokazala da andezitna stijena ima dobru kvalitetu stijenske mase i vrlo povoljnu stabilnost kosina. Ipak, može doći do klinastih slomova stijena na koje utječu spojeni stupovi u stijenskoj masi. Analiza također pokazuje da integralni diskontinuiteti prisutni u andezitnim ležištima znatno utječu na srednje vrijednosti duljine diskontinuiteta, razmak diskontinuiteta i snagu stijene. Međutim, integralni diskontinuiteti malo utječu na iznos mase stijene na kosini (MSK). Stoga se preporučuju detaljne studije o doprinosu integralnih diskontinuiteta svojstava iznosa stijenske mase (ISM) i mase stijene na kosini (MSK) različitih vrsta stijena.

\section{Ključne riječi:}

andezitna stijena, spojeni stupovi, integralni diskontinuitet, ocjena stijenske mase, klasifikacija stijenske mase

\section{Authors contribution}

Alvian R. Yanuardian (M.Eng, assistant researcher, engineering geology) initialized the idea, provided the kinematic analysis, presented the results, and performed the field work. Koko Hermawan (M.Eng, assistant researcher, rock mechanics) provided the rock mass quality analysis, recorded Schmidt hardness, and performed the field work. Antonina Pri Martireni (M.Eng, assistant researcher, geomechanics) provided the SMR analysis, redrew the illustration and geological map, and helped with field work. Adrin Tohari (Dr., senior researcher, geotechnical engineering) managed the whole process from the beginning to the end and provided the statistics analysis. 